\title{
Four Dimensions of Women's Empowerment in Tourism: Case Study of Indrayanti Beach, Yogyakarta, Indonesia
}

\author{
Arisanti Ayu Wardhani and Indah Susilowati*
}

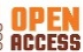

\author{
AFFILIATION: \\ Department of Economics, Faculty \\ of Economics and Business, \\ Universitas Diponegoro, Central \\ Java, Indonesia
}

\section{*CORRESPONDENCE:}

prof.Indah@gmail.com

THIS ARTICLE IS AVALILABLE IN: http://journal.umy.ac.id/index.php/esp

DOI: 10.18196/jesp.v22i2.10745

\section{CITATION:}

Wardhani, A.A., \& Susilowati, I. (2021). Four Dimensions of Women's Empowerment in Tourism: Case Study of Indrayanti Beach, Yogyakarta, Indonesia. Jurnal Ekonomi \& Studi Pembangunan, 22(2), 170-184.

\section{ARTICLE HISTORY}

\section{Received:}

04 Jan 2021

Revised:

19 Apr 2021

09 Aug 2021

31 Aug 2021

Accepted:

07 Sep 2021
Abstract: The emergence of sustainable tourism has led to a new tourism concept called ecotourism. Ecotourism has the principle of environmental preservation and the local communities' welfare produces a significant impact on indigenous people in the area. This is because the local community is involved in managing sustainable tourism. Women who are part of the community have the same opportunities as men in accessing opportunities from ecotourism activities. Based on empirical research results, tourism activities create alternative jobs for women to be more independent economically, including the fact that the participation of women in tourism activities has a positive impact on them socially. Empowering women is an important part of community welfare efforts in the scope of tourism, so that women's empowerment is important in the tourism development process. This study aims to analyze the ongoing empowerment of women and what factors are the drivers and barriers to empowerment in Indrayanti Beach as one of the leading destinations in Gunungkidul Regency as seen from four dimensions (economic, social, political, and psychological). The mixed-method approach has been used in research. It was found that the level of women's empowerment in Indrayanti Beach had shown a good enough score with the highest average score in the economic dimension, namely 7.64, where women economically have received a positive impact from Indrayanti Beach. The lowest average score is on the political dimension, with a value of 5.82 . Women politically still do not have awareness if their role is important for the sustainability of Indrayanti Beach tourism. For the social dimension, the average is 6.81 , and the psychological dimension on average is 7.47 , where women feel socially and psychologically empowered quite well. The main driver of women's empowerment is the opportunity and permission from their families to participate in tourism activities. The main obstacle to women's empowerment is the low self-confidence due to skills that have not been maximized.

Keywords: Empowerment of Women; Gender; Tourism; Indrayanti Beach JEL Classification: J16, Z32

\section{Introduction}

Tourism is a potential sector that can become a mainstay for Indonesia in improving the economy and development, both at the national and regional levels. Natural wealth and abundant diversity are special features for Indonesia in the world's eyes, with diverse geographic conditions and cultural properties being the only attraction for local and foreign tourists to come to visit. Tourism has become a necessity for some people. 
The great interest of the community to do tourism makes tourism an important sector for Indonesia. Indonesia has high hopes for the tourism sector as an export commodity that can replace oil and gas' future role (Sedarmayanti, 2014). Abundant potential can be a way for Indonesia to realize this dream. In the last ten years, tourism activities, especially in developing countries, have begun to diversify tourism objects by seeing the potential for alternative tourism to tackle mass tourism which has brought disastrous effects (Suardana, 2012).

Women as part of society have an excellent opportunity to access employment in the tourism sector. Conceptually, tourism activities will create new jobs that women can use to improve their standard of living (Setyawati, 2011; Tuwu, 2018). Women's participation in accessing the same world of work as men will later create a gender problem. Meanwhile, the UN has defined gender equality and women's workforce as the goal of sustainable development. From the women's perspective, it has contributed to empowerment. Furthermore, several researchers have looked at women's perceptions of factors such as having a job, income, and freedom to make decisions that contribute to empowerment, especially women who have found employment in the tourism industry in developing countries (Aghazamani et al., 2020).

It is crucial to conduct gender research in tourism to explain the current condition of gender roles in the tourism sector (Alrwajfah et al., 2020). Gender is considered a sensitive issue, and primarily gender relations have been influenced by tourism developments over time (Alrwajfah et al., 2020). One important aspect of encouraging and promoting gender equality is women's empowerment that focuses on identifying and correcting power imbalances and giving women the opportunity to determine their own lives (Irandu \& Shah, 2014). Empowerment is a potential strategy to improve society's economy and socio-culture (Susilowati et al., 2008). Therefore, women's empowerment is a crucial point to improve the equality and economy of society. With empowerment, women can develop themselves and explore their potential. The emergence of tourism activities on Indrayanti Beach provides opportunities for women around the coast to develop their potential, especially in tourism activities.

Gunungkidul Regency, as a regency directly adjacent to the Indian Ocean, has enormous marine tourism potential. Indrayanti Beach is one of the beaches that is currently experiencing rapid development which is a sign of becoming a well-known tourist attraction. The number of visits that have increased every year.

The concept of ecotourism, which includes community empowerment, should be able to empower women optimally. Great opportunities for the emergence of new employment opportunities can become an arena for women to play an active role in economic activities on Indrayanti Beach. In the implementation of women's empowerment, there are still obstacles in it. Based on the results of interviews with female informants who participate in tourism activities, they still rely on their own skills and knowledge without any skills development training, so that the empowerment of existing women is still not optimal. 


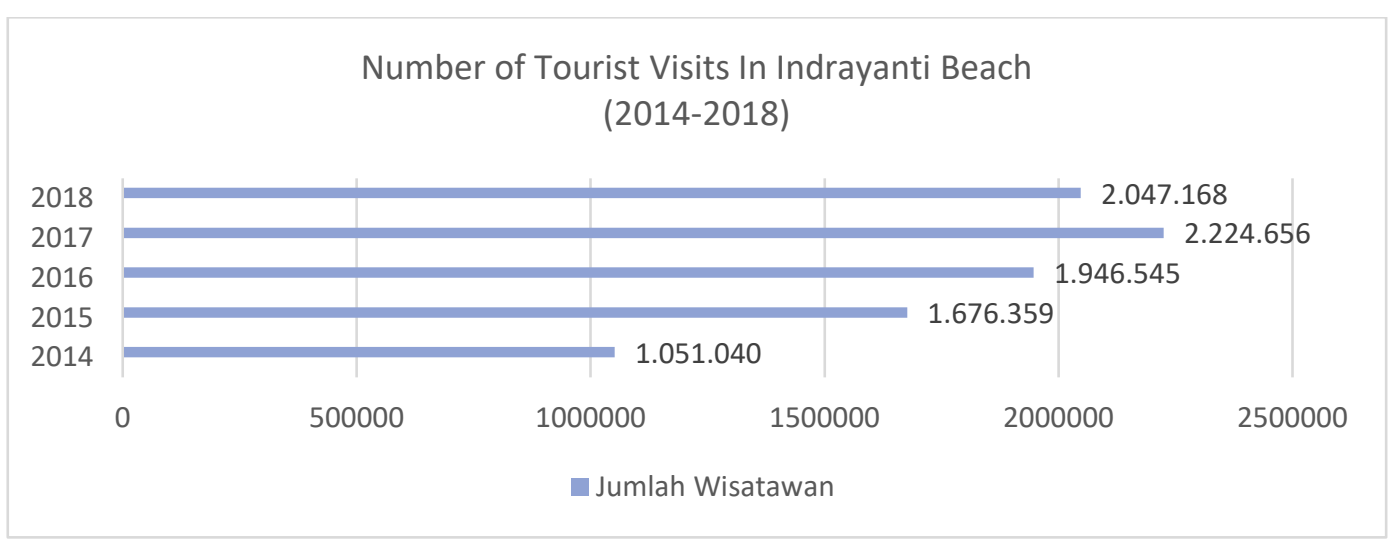

Figure 1 Number of Tourist Visits In Indrayanti Beach (2014-2018)

Source: Government Tourism Office (2018)

Women and men have the same role in tourism activities. Still, women have not been able to take part in existing decision-making. This is because women do not have foresight in tourism development, so women's roles are still only in the domestic corridor. The decision-making corridor still depends on men (Tulle, 2016; Sabina \& Nicolae, 2013). According to experts' perceptions, gender in ecotourism can be handled if the management is carried out with a participatory approach, wherein its development the community is the main target. Knowledge of the nature of the community is needed before ecotourism. Its implementation must support poor, less powerful community groups, which often involve women in it, to achieve the goal of ecotourism as conservation tourism and give priority to local communities (Scheyvens, 2000).

There are three reasons gender in ecotourism is important. The first is that gender becomes a way of promoting good natural resource management and conservation based on ecotourism. Second, it ensures that ecotourism development benefits from the skills and knowledge of various communities. Third, gender equality has become a basis of human rights that have been approved in the millennium development. These three reasons make women and men have equality in making decisions regarding the development and management of ecotourism. Women and men must also be fair in the use of ecotourism (Irandu \& Shah, 2014).

Scheyvens (2000) states that four dimensions determining women's empowerment in tourism activities for developing countries consist of economic, social, political, and psychological dimensions. These 4 (four) dimensions are important (Irandu \& Shah, 2014) to see how the role of ecotourism in improving women's welfare in improving and economic independence (economic aspects), having a voice in decision making related to ecotourism (political aspects), the opportunity in participating in activities that are developed by the community (social aspect), and the opportunity in establishing themselves and have a sense of pride in themselves and the local culture that the region has (psychological aspects) (Rahayu, 2018; Irandu \& Shah, 2014). Community-based ecotourism, in which the community is actively empowered economically, socially, politically, and psychologically, is a key element of sustainable tourism (Ertac \& Tanova, 
2020). Empowerment is considered a failure in ecotourism if there is a conversion of customary land functions, crime, fighting, prostitution, begging, and local communities' involvement in ecotourism activities (Purnomo, 2018).

Meanwhile, the equality of women and men in coastal areas, especially in tourism development, is still not running well. In the labor division, women's role is still only in the household sector, such as taking care of children and doing household chores, while women who work in the public sector or work to earn a living are still small. Women who earn a living are encouraged because men can no longer make a living (Setyawati, 2011). Empowerment of women in coastal areas, especially coastal tourism, is still not maximal even though women have been involved in tourism, but women still have a position below men (Suardana, 2012). Coastal tourism development is inseparable from the role of women in it. However, women who participate in tourism activities are mostly related to the domestic sector or are related to cooking. In contrast, other tourism activities requiring special skills are still dominated by men considered to have more qualified abilities than women.

Research related to women's empowerment in tourist objects has been widely carried out in Indonesia and the world, but there are not many existing empirical studies that explore women's empowerment through four dimensions, namely economic, social, political, and psychological. Meanwhile, to see women's empowerment itself can not only be seen from one side but the other side because the problem of empowerment is a complex problem which requires a holistic view. According to Scheyvens (2000), the problem of empowering women, especially in developing countries, must be seen from many sides because tourism development is related to the economy and is multidimensional, and does not only focus on the economy. This research focuses more on seeing the level of empowerment based on four sides, namely the economy, social, politics, and psychology of women involved in tourism activities on Indrayanti Beach. Research on women's empowerment in previous studies also uses the dimensions consisting of economic dimensions (Irandu \& Shah, 2014; Ranasinghe \& Pradeepamali, 2019; Scheyvens, 2000; Suardana, 2012), Social (Irandu \& Shah, 2014; Ranasinghe \& Pradeepamali, 2019; Scheyvens, 2000; Rahayu, 2018; Boley \& McGrehee, 2014), Politics (Setyawati, 2011; Irandu \& Shah, 2014; Ranasinghe \& Pradeepamali, 2019; Scheyvens, 2000; Rahayu, 2018; Boley \& McGrehee, 2014), Psychology (Oladipo, 2010; Batool \& Ahmed, 2016; Irandu \& Shah, 2014; Ranasinghe \& Pradeepamali, 2019; Scheyvens, 2000; Rahayu, 2018; Boley \& McGrehee, 2014).

This study contributes to providing information on how the conditions for women's empowerment have been running and what factors are the drivers and barriers to empowerment at Indrayanti Beach. The method on contributing to the research arsenal is following the conditions as one of the mainstay tourist destinations of Gunungkidul Regency by identifying the level of women's empowerment seen from four dimensions, namely economic, social, political, and psychological by using calculations based on the concept of RETS (Resident Empowerment through Tourism Scale) with modifications to include economic aspects in it. RETS is a concept formulated by by Boley and McGehee (2014) by adapting the four dimensions of empowerment by Scheyvens (2000). Still, it 
does not include the economic dimension, so modifications were made to include the economic dimension in this study. In addition, in-depth interviews were conducted with key persons who have more knowledge about women's empowerment in Indrayanti Beach to find out the driving and inhibiting factors of empowerment.

\section{Research Method}

This research was conducted from June to July 2020 at the Indrayanti Beach tourist attraction, located in Tepus Village, Tepus District, Gunungkidul Regency, Yogyakarta Special Region Province. The sample in this study used snowballing sampling to select informants according to the criteria to answer the research objectives, namely women who are active in Indrayanti Beach tourism activities. Primary data in this study consisted of 48 informants. Secondary data were obtained from the Statistics Indonesia (BPS) both from the Yogyakarta Special Region Province and from the Kaputan Gunungkidul, the Ministry of Tourism, the Tourism Office of the Special Region Yogyakarta and Gunungkidul Regency, and the Kelurahan Tepus Village, Gunungkidul Regency.

The approach used in this research is the Mixed method which combines qualitative and quantitative approaches. The mixed-method approach provides accurate analytical results in assessing the problems to be studied in research (Creswell, 2014). The quantitative method used is the concept of Resident Empowerment through Tourism Scale (RETS) proposed by Boley \& McGrehee (2014) by modifying the addition of an economic dimension to see how ecotourism can affect women's economic life individually. In this study, the analysis was carried out by looking for each indicator's average in four dimensions. In the economic dimension, the assessment was seen from how many opportunities women had to access the labor market and better income. The social dimension of the evaluation is based on the opportunity for women to be more able to mingle with the community and participate in community activities. The political dimension of assessment is seen from how women have the power to make decisions and express their thoughts in tourism development. The psychological dimension of evaluation is seen from the feeling of pride in women towards their local culture and a sense of wanting to preserve the nature of local people's tourism locations. The assessment is carried out based on 1 to 10 by determining the conventional scale scoring score as follows:

Table 1 Scoring Scale

\begin{tabular}{cc}
\hline Scoring Scale & Interpretation \\
\hline $1-2$ & Very Low \\
$3-4$ & Low \\
$5-6$ & Medium \\
$7-8$ & High \\
$9-10$ & Very High \\
\hline
\end{tabular}

Source: Rahayu (2018) with modifications 
The greater the average grade in each aspect, the better women's empowerment in Indrayanti Beach (Rahayu, 2018). Empowerment requires a multidisciplinary approach because empowerment is a complex problem (Waridin et al., 2018). Seeing empowerment not only sticks to one point of view but must be seen from various sides, namely economic, social, political, and psychological (Scheyvens, 2000; Irandu \& Shah, 2014).

The qualitative method used is an in-depth interview and Triangulation. In-depth interviews and triangulation research were conducted to validate the drivers and barriers of women's empowerment based on the results of the average four dimensions of empowerment (economic, social, political, psychological) so that they could explain the average results of the four dimensions better and could explore further what are the driving and inhibiting factors for women's empowerment in Indrayanti Beach.In-depth interviews were conducted with key persons consisting of the Gunungkidul Regency Tourism Office, business people around Indrayanti Beach, academics, and the tourism community on Indrayanti Beach (Pokdarwis). The in-depth interviews were then analyzed using ATLAS Ti software, where ATLAS Ti can help analyze the results of the data obtained from in-depth interviews by providing coding to each data to provide convenience for researchers in drawing conclusions.

\section{Result and Discussion}

\section{Gender Roles in Tourism Activities in Indrayanti Beach}

Both men and women conduct tourism activities in Indrayanti Beach, so there is no difference in the implementation of tourism activities in Indrayanti. Both women and men have equal opportunities to participate in beach activities. However, in several activities, the role of women is still relatively small compared to men. The vital roles of women and men in tourism activities on Indrayanti Beach can be seen in Table 2.

Table 2 Gender Roles in Tourism Activity Data

\begin{tabular}{ccc}
\hline Tourism Activities & Male & Female \\
\hline Food Processing & 10 & 16 \\
Souvenir Provider & 4 & 6 \\
Tourism Service Providers & 9 & 3 \\
\hline
\end{tabular}

Women's role in tourism activities on Indrayanti Beach is most significant in food processing which is 16 , and souvenir providers at $60 \%$. For tourism service providers, women's role is still too small because the role of women involved in these activities is very small. Most of the women participate only as seasonal workers when the beach is crowded. Apart from renting mats and umbrellas, photography service providers are still dominated by men. This happens because women's ability to operate a camera is still not as good as men's, so women only get the role of photo printing. The management of tourism in Indrayanti Beach is also dominated by men in the core management, both chairman, treasurer, and secretary. 


\section{Gender Empowerment Based on Economic, Social, Political, and Psychological Aspects}

Table 3 shows the average level of women's empowerment as seen from the four aspects of empowerment presented by Scheyvens (2000), consisting of economic, social, political, and psychological empowerment. To see women's empowerment based on these aspects, each aspect has indicators that can show how women's empowerment is running in Indrayanti Beach and is consequently measured using a conventional scale of 1 to 10 , which means that the higher the value, the better the existing empowerment.

Table 3 The Average of Gender Empowerment Based on Economic, Social, Political, and Psychological Dimensions

\begin{tabular}{|c|c|c|c|c|c|}
\hline Aspect & Indicator & Value & SD & Mean & Interpretation \\
\hline \multirow[t]{4}{*}{ Economic } & $\begin{array}{l}\text { The emergence of employment } \\
\text { opportunities after tourism } \\
\text { activities. }\end{array}$ & 7.88 & 1.28 & \multirow[t]{4}{*}{7.64} & \multirow[t]{4}{*}{ High } \\
\hline & $\begin{array}{l}\text { An increase of income after } \\
\text { participating in tourism } \\
\text { activities. }\end{array}$ & 7.62 & 1.35 & & \\
\hline & $\begin{array}{l}\text { An opportunity or probability of } \\
\text { getting a better income. }\end{array}$ & 7.46 & 1.36 & & \\
\hline & $\begin{array}{l}\text { Financial stability after } \\
\text { participating in tourism } \\
\text { activities. }\end{array}$ & 7.62 & 1.41 & & \\
\hline \multirow[t]{3}{*}{ Social } & $\begin{array}{l}\text { Feeling more unified with other } \\
\text { societies. }\end{array}$ & 6.62 & 1.64 & \multirow[t]{3}{*}{6.81} & \multirow[t]{3}{*}{ Medium } \\
\hline & $\begin{array}{l}\text { There is an increase in } \\
\text { enthusiasm for socializing. }\end{array}$ & 7.00 & 1.44 & & \\
\hline & $\begin{array}{l}\text { The emergence opportunity to } \\
\text { participate in societal activities }\end{array}$ & 6.81 & 1.37 & & \\
\hline \multirow[t]{3}{*}{ Politic } & $\begin{array}{l}\text { Having a right in decision- } \\
\text { making related to the } \\
\text { development of tourism } \\
\text { activities. }\end{array}$ & 5.31 & 1.22 & \multirow[t]{3}{*}{5.82} & \multirow[t]{3}{*}{ Medium } \\
\hline & $\begin{array}{l}\text { Having the right to vote in beach } \\
\text { development planning. }\end{array}$ & 5.77 & 1.36 & & \\
\hline & $\begin{array}{l}\text { Having the right to express ideas } \\
\text { and thoughts in tourism } \\
\text { development. }\end{array}$ & 6.38 & 1.51 & & \\
\hline \multirow[t]{4}{*}{ Psychology } & $\begin{array}{l}\text { The emergence of pride to be } \\
\text { part of Tepus society (as a part } \\
\text { of Indrayanti Beach). }\end{array}$ & 7.88 & 1.55 & \multirow[t]{4}{*}{7.47} & \multirow[t]{4}{*}{ High } \\
\hline & $\begin{array}{l}\text { The emergence of a particular } \\
\text { feeling as a consequence of } \\
\text { tourist visits. }\end{array}$ & 7.62 & 1.89 & & \\
\hline & $\begin{array}{l}\text { Awareness of uniqueness that } \\
\text { can be told. }\end{array}$ & 7.46 & 1.41 & & \\
\hline & $\begin{array}{l}\text { Awareness of environment } \\
\text { preservation tourism activities. }\end{array}$ & 7.62 & 1.45 & & \\
\hline
\end{tabular}




\section{Economic Empowerment}

Economic empowerment is a dimension of empowerment that impacts the local community's economy due to the development of tourism activities in their area. Economic empowerment is seen when the emergence of tourism activities gives the women's opportunity to access the labor market and improve their welfare. Based on Table 3, women's economic empowerment has shown an excellent average value, namely 7.64 .

The first indicator, "The emergence of opportunity or working opportunity after tourism activities," has a high value of 7.88. This average shows that the existence of tourism activities on Indrayanti Beach has a positive impact on women, especially the opportunity to access the labor market compared to before tourism activities. With the ease of women entering into tourism activities, it gives women the strength to be more financially independent. This is indicated by indicators of economic empowerment "There is an increase in income after participating in tourism activities" and "Financial stability after participating in tourism activities" with each value of 7.62, then the indicator "There is an opportunity to get a better income" with an average value -average 7.46. The participation of women in tourism activities gives them financial independence because it contributes to the alleviation of their family's economic condition. Initially, they are only housewives or farmworkers who are economically unstable and upon joining the activities in ecotourism, they have become women who can help their husbands and families pay for their daily needs.

Tourism activities on Indrayanti Beach have a positive impact on women economically. Economic empowerment for women runs positively. These results are not following the study conducted by (Irandu \& Shah, 2014) in which women cannot access jobs in the labor market in the tourism sector and only act as housewives. The difference in results is due to the fact that women in Indrayanti Beach have intense support from their families.

\section{Social Empowerment}

Social empowerment is a dimension of empowerment related to the closeness between individuals and groups, increased cohesiveness between communities, and opportunities to participate in existing community activities. Social empowerment occurs when women have the opportunity to be able to participate in activities in society. The average of social empowerment is 6.81 , which shows that socially, women have felt the impact, even though it is not too massive.

On the indicator of social empowerment, "Feeling of being more united with other societies" has a value of 6.62 . The value shows that Indrayanti Beach tourism activities in the Tepus Village area give women the opportunity to be more integrated with society. This encourages women to be more enthusiastic in establishing relationships with the society around them then, as shown by the value of the social empowerment indicator "There is an increase in enthusiasm for socializing," indicating a high enough value of 7.00 and an indicator of "The opportunity to participate in social activities" with value 6.81 . 
The three values of social indicators show that tourism activities on Indrayanti Beach encourage women to be more socialized with their surrounding societies to work together in building tourism. Furthermore, Indrayanti Beach's activities encourage women to get involved with social activities such as the women's lottery club in Pokdarwis Kompak as beach managers, which women mostly carry out.

Socially, women have a positive impact on the emergence of Indrayanti Beach. As a result of the emergence of tourism activities, they indirectly play an important role in tourism development by forming activities that can encourage tourism development in Indrayanti Beach. The result is following the result of the study conducted by Scheyvens (2000) in which the emergence of tourism provides an increase in interaction between them. Individuals and groups build better tourism together. The social empowerment that appears on Indrayanti Beach is under the results of Scheyvens' study (2000), where the emergence of tourism provides increased interaction between communities. Individuals and groups together build better tourism.

\section{Political empowerment}

Political empowerment is a dimension of empowerment wherein women can express their aspirations, voices, and decision-making in tourism. Political empowerment occurs when women realize that they have power in making decisions related to tourism activities. The average value of political empowerment for women in Indrayanti Beach is 5.82 , indicating that politically, women have not been empowered optimally.

The first indicator, "Has the right to make decisions related to tourism development," has a value of 5.31, the indicator "Has the right to vote in beach development planning" with a value of 5.77, and the indicator "Has the right to utter ideas and thoughts in tourism development" which has a value 6.38. Based on the three indicators of political empowerment, the value tends to be low compared to other empowerment aspects.

The low level of political empowerment occurs because women who participate in tourism activities are still unaware of the importance of their opinions on tourism development. Opportunities in expressing statements are welcome and facilitated by Pokdarwis Kompak as the beach manager. Pokdarwis Kompak has provided a chance for all members to speak ideas or suggestions in developing the beach. However, women still do not dare to participate in voicing their ideas and thoughts based on the lack of insight they have regarding tourism development.

Besides the lack of awareness, women's political empowerment is still hampered by voting ownership. Although the opportunity is open for women to make decisions, because decisions are made by deliberation, decision-making is still carried out by the core management, who are primarily men, both chairperson, secretary, and treasurer. Almost all women become members only and are more likely to follow all the core management decisions. 
Politically, women are not appropriately empowered due to support by the low value on each political indicator. Women on Indrayanti Beach are still unable to take advantage of the opportunity to participate in tourism development. The result of political empowerment is similar to the study conducted by Scheyvens (2000). In decision-making on tourism development, women are more likely to follow men and leave their voices to men.

\section{Psychological empowerment}

Psychological empowerment is a dimension of empowerment that has a psychological influence on women due to the emergence of tourism activities in their area. The average value of psychological empowerment is 7.47. This value has shown women's psychological empowerment after tourism activities have increased significantly.

The indicator "The emergence of pride in being part of the Tepus society (as the location of Indrayanti Beach)" has a value of 7.88. The high value shows that with the presence of tourism activities, women are proud of their area because many tourists visit to see the natural beauty in their area. The women's pride encourages them to have an awareness that they are special in becoming part of the place where they live, and the existence of awareness of the characteristics they can develop in attracting tourists. It can be seen from two psychological empowerment indicators, "The emergence of a special feeling due to tourist visits" and "Awareness of the uniqueness that can be told" with values of 7.62 and 7.46, the feeling of being particular and aware of their uniqueness occurs because of the interaction between women as tourism service providers and tourists. The three indicators encourage women to feel belonging to the tourism objective, namely Indrayanti Beach. This feeling of belonging indirectly encourages women to maintain the sustainability of tourism objects to maintain their sustainability. This is supported by the indicator value of "Awareness of the conservation of the tourism environment," namely 7.62 .

\section{Driving and Inhibiting Factors of Women Empowerment}

Empowerment of women in Indrayanti Beach based on economic, social, political, and psychological dimensions shows that the existing women's empowerment has been running quite well from each dimension. It is good that women's empowerment cannot be separated from the driving factors, but along the way, women's empowerment also still faces an obstacle. The driving and inhibiting factors for women's empowerment are based on in-depth interviews with key persons who have direct involvement in tourism activities in Indrayanti Beach. They have a better understanding of the drivers and barriers of women's empowerment running on Indrayanti Beach. 


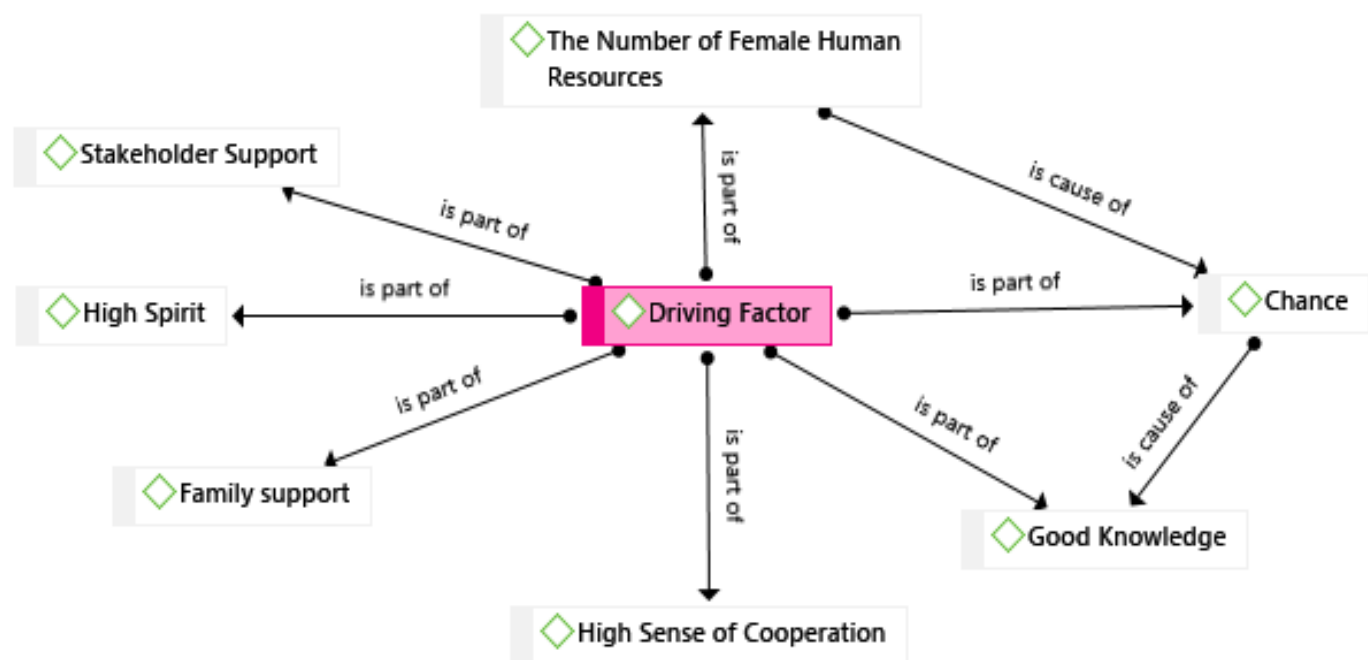

Figure 2 Illustration of the Driving Factors for Empowerment in Indrayanti Beach with ATLAS Ti

Based on the results from ATLAS Ti, it shows that several factors drive women's empowerment in Indrayanti Beach. The participation of women in tourism areas has become a natural thing where women on Indrayanti Beach have a high spirit and sense of cooperation in the tourism development process. This cannot be separated from the support from the closest parties, such as families who do not restrain them from participating in the tourism area. In addition, in the tourism sector, the highest absorbed human resources are women with a fairly good knowledge of tourism potential. Women can be encouraged to participate in tourism activities actively. This is reinforced by a statement from the head of planning for the Gunungkidul Tourism Office.

"If we look at the labor sector in Indrayanti, many women are also absorbed as workers, and women are at the forefront of the Indrayanti area. Currently, women are no longer looked down upon, and now many women have joined the work and men themselves have also not prohibited women from working."

Support from relevant stakeholder parties also encourages them to participate in tourism activities. They are given facilities to participate in tourism activities, such as participating in forums facilitated by the Tourism Office and Pokdarwis in Indrayanti Beach. This follows what was conveyed by the Head of Industry and Tourism Institutions of the Gunungkidul Tourism Office.

"...their involvement cannot be separated from development planning, such as the Musrembang involving women and pokdarwis, as well as the joint forum of regional apparatuses that have also involved them. In addition, for the development of human resources, especially Pokdarwis and Sapta Pesona, there are many women involved. In addition, cross-sectoral support, both professional and related institutions, is very high. Third, there is a high sense of kinship and mutual cooperation that still exists in the community." 


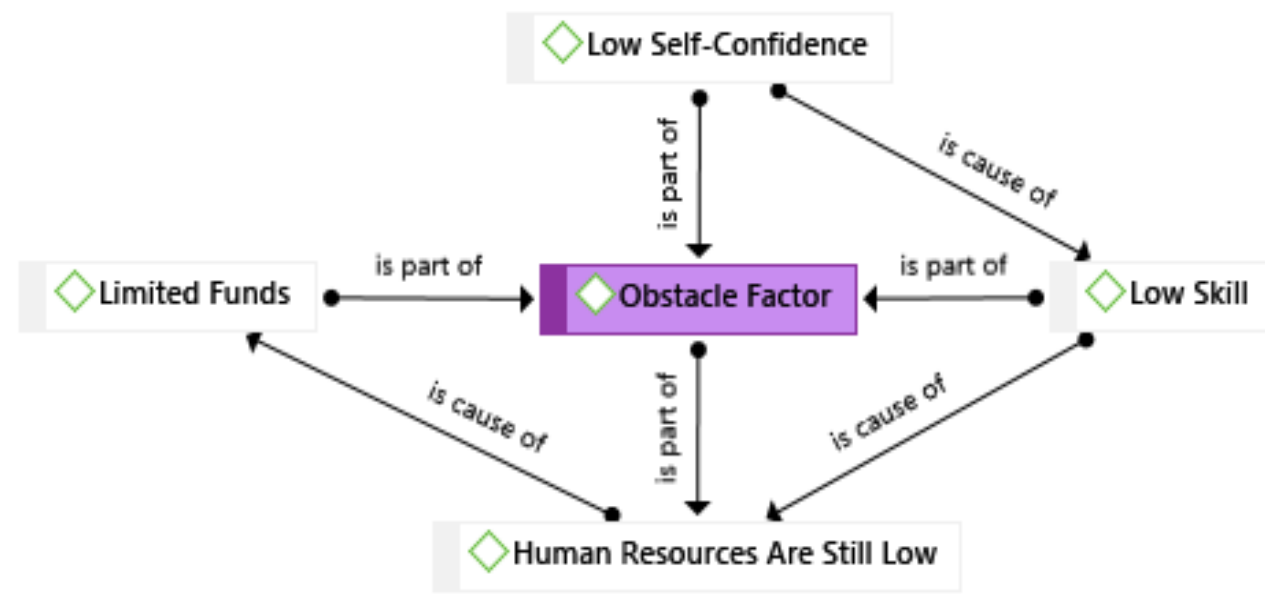

Figure 3 Illustration of Inhibiting Factors for Empowerment in Indrayanti Beach with ATLAS Ti

The empowerment of existing women is also still experiencing obstacles. Women still experience a lack of confidence to participate in tourism activities because they feel that their skills are still low or only limited to the knowledge they know. The lack of training contributes to their inability to innovate which is primarily due to the very limited funds for training. This statement was reinforced by the Head of Industry and Tourism Institutions, Gunungkidul Tourism Office.

\footnotetext{
"For the inhibiting factor, Ms. may still be closely tied to her human resources, such as limited human resources for tourism actors, the type of coaching needed varies according to the profession, while funds are limited and changing the mindset to apply behavior according to tourism rules must be carried out continuously, temporarily, and the costs for training are very limited."
}

Human resources that are still low, with the majority only having education up to high school level, are one of the obstacles in empowering women in Indrayanti, especially in their thoughts regarding beach development and self-improvement, even though forums for women are already available from both the Pokdarwis and the government in terms of this is the Department of Tourism. The Secretary of Pokdarwis conveyed the statement:

"........there is an inhibiting factor when there is a program that we make, sometimes they don't immediately accept it, maybe because of their background, they don't have enough human resources, so sometimes they don't realize that the procurement of a facility is important, for development and they accept it, we are like this, it's already good, I see. Women are scared too."

\section{Conclusion}

The condition of women's empowerment on Indrayanti Beach can be seen from the average results of four dimensions of trust. Based on the Resident Empowerment concept 
through Tourism Scale (RETS), empowering women who walk on Indrayanti Beach from one dimension to another shows the results of a different average value with the highest average value of empowerment being in the economic dimension. The lowest average empowerment value is the political dimension.

The dimension of economic empowerment has the highest average value compared to other dimensions of women's empowerment, namely 7.64, which is in the high category. The high average value shows that women in Indrayanti Beach are economically well empowered and have acquired positive benefits from it economically. Women in Indrayanti Beach feel that the emergence of tourism activities provides them with opportunities to get better jobs and incomes.

The psychological empowerment dimension is the highest in second place, with an average value of 7.47, which is included in the high category. The high average value of empowerment shows that women who participate in tourism activities on Indrayanti Beach feel well empowered psychologically. Women on Indrayanti Beach have a feeling of pride in the area and culture they have. In addition, women in Indrayanti Beach already have a sense of preserving the environment of Indrayanti Beach.

The social empowerment dimension has an average empowerment value of 6.81 , which is in the medium category. The average value of empowerment in the sociological dimension is currently showing that socially women on Indrayanti Beach already feel empowered even though they still have not had such a significant impact on women. They already have a greater sense of interacting with the community around them and engaging in community activities.

The dimension of political empowerment has the lowest average value of empowerment compared to other dimensions of empowerment, namely 5.82, which is in the medium category. Politically, women already have a place to express their opinions and ideas regarding tourism development. However, women still feel that their opinions are not needed and are more likely to follow men's voices. This is because women feel that they do not know anything related to tourism development efforts, so they consider men's voice to represent them.

Several factors encourage women's empowerment so that empowerment can run quite well; namely, they have opportunities, enthusiasm and a high sense of cooperation, support from large families, and a large number of female human resources with good knowledge of tourism potential. The role of supporting stakeholders also encourages them to participate in tourism activities actively. Empowerment also still has several obstacles where women still experience insecurity due to low skills and lack of training that they can provide, and their ability to innovate is still lacking. The lack of training women receive in Indrayanti Beach is because the funds for training are very limited. Women's resources have not been able to develop their potential to the fullest.

This research can provide an overview regarding the empowerment of women in Indrayanti Beach tourism to become one of the important literature in future policy 
making related to women's empowerment in coastal tourism locations. This research has its limitations, thus it is important to carry out further research related to empowerment where it is seen from the women's side. It is also important to know empowerment between men and women to find out more about empowerment between genders.

\section{References}

Aghazamani, Y., Kerstetter, D., \& Allison, P. (2020). Women's perceptions of empowerment in Ramsar, a tourism destination in northern Iran. Women's Studies International Forum, 79(March-April), 102340. https://doi.org/10.1016/i.wsif.2020.102340

Alrwajfah, M. M., Almeida-García, F., \& Cortés-Macías, R. (2020). Females' perspectives on tourism's impact and their employment in the sector: The case of Petra, Jordan. Tourism Management, 78(June). https://doi.org/10.1016/j.tourman.2019.104069

Batool, S. A., \& Ahmed, H. K. (2016). Economic and psycho-social determinants of psychological empowerment in women. Pakistan Journal of Social and Clinical Psychology, 14(1), 21-29.

Boley, B. B., \& McGehee, N. G. (2014). Measuring empowerment: Developing and validating the Resident Empowerment through Tourism Scale (RETS). Tourism Management, 45, 85-94. https://doi.org/10.1016/j.tourman.2014.04.003

Creswell, J.W. (2014). Research design qualitattive, quantitative, and mixed methods approaches (4th $E$ d.). Thousand Oaks, CA: Sage.

Ertac, M., \& Tanova, C. (2020). Flourishing Women through Sustainable Tourism Entrepreneurship. Sustainability, 12(14), 5643. https://doi.org/10.3390/su12145643

Government Tourism Office. (2018). Tourism Statistics 2018. Yogyakarta Special Region Tourism Office. Retrieved from https://visitingjogja.com/19962/statistik-pariwisatadiv-2018/

Irandu, E. M., \& Shah, P. (2014). The role of ecotourism in promoting women empowerment and community development: some reflections from Kenya. Journal of Tourism and Hospitality Management, 2(6). https://doi.org/10.17265/23282169/2014.06.002

Oladipo, S. (2010). Psychological empowerment and development. Edo Journal of Counselling, 2(1), 118-126. https://doi.org/10.4314/ ejc.v2i1.52661

Purnomo, A. M. (2018). Pemberdayaan sosial dalam pengembangan ekowisata di Pekon Kiluan Negri, kabupaten Tanggamus, provinsi Lampung. Jurnal Kesejabteraan Sosial, 2(2), 110-121. https://doi.org/10.31326/jks.v2i02.155

Rahayu, A. T. (2018). Gambaran keberdayaan perempuan di desa wisata pentingsari berdasarkan Resident Empowerment through Tourism Scale (RETS). Tourisma: Jurnal Pariwisata, 1(1), 1-11. https://doi.org/10.22146/gamajts.v1i1.36313

Ranasinghe, R., \& Pradeepamali, J. (2019). Community empowerment and their support for tourism development: an inquiry based on resident empowerment through tourism scale. Journal of Tourism and Services, 10(19), 55-76. https://doi.org/10.29036/jots.v10i19.96

Sabina, J. M., \& Nicolae, J. C. (2013). Gender trends in tourism destination. Procedia - Social and Behavioral Sciences, 92, 437-444. https://doi.org/10.1016/i.sbspro.2013.08.698

Scheyvens, R. (2000). Promoting women's empowerment through involvement in ecotourism: experiences from the third world. Journal of Sustainable Tourism, 8(3), 232249. https://doi.org/10.1080/09669580008667360

Sedarmayanti, S. (2014). Kebudayaan \& industri pariwisata. Bandung: Refika Aditama. 
Setyawati, Y. E. (2011). Pemberdayaan perempuan dalam pengembangan pariwisata di pantai pandansimo. Jurnal Riset Daerah, 10(2), 1524-1549.

Suardana, I.W. (2012). Pemberdayaan perempuan di kawasan kuta sebagai upaya peningkatan kualitas pariwisata Bali. Piramida, 6(2), 1-16. Retrieved from https://ojs.unud.ac.id/index.php/piramida/article/view/3002

Susilowati, I., Widowati, I., \& Agustini, T.W., \& Raharjo, A.B. (2008). Empowering A-B-G-C to Promote Simping Clam (Amusium pleuronectes) as one of the way out line to raise the welfare of Fishers and Regional Income in Northern-Coast of Central JavaIndonesia: with Special Reference to Brebes Regency as the Pilot Project. IIFET 2008 Vietnam Proceedings. Retrieved from https://core.ac.uk/download/pdf/10197734.pdf

Tulle, K. E. D. (2016). Studi tentang partisipasi perempuan dalam pengambilan keputusan Musyawarah Leo di kabupaten Rote Ndao. Paradigma, Jumal Kajian Budaya, 6(1), 55-73. https://doi.org/10.17510/paradigma.v6i1.81

Tuwu, D. (2018). Peran pekerja perempuan dalam memenuhi ekonomi keluarga: dari peran domestik menuju sektor publik. Al-Ižab: Jurnal Hasil-Hasil Penelitian, 13(1), 63-76. https://doi.org/10.31332/ai.v13i1.872

Waridin, W., Dzulkhijiana, A., \& Mafruhah, I. (2018). Community empowerment in rural infrastructure development program. Economic Journal of Emerging Markets, 10(1), 8-14. https://doi.org/10.20885/ejem.vol10.iss1.art2 